\title{
Protected methionine as a methyl-group donor for dairy cows fed diets with different starch sources in the transition period
}

\author{
J.A. Strzetelski ${ }^{1,5}$, Z.M. Kowalski ${ }^{2}$, J. Kowalczyk ${ }^{3}$, F. Borowiec ${ }^{2}$, \\ S. Osięgłowski ${ }^{4}$ and K. Ślusarczyk ${ }^{1}$
}

\author{
${ }^{1}$ National Research Institute of Animal Production, \\ Department of Animal Nutrition and Feed Science \\ 32-083 Balice, Poland \\ ${ }^{2}$ University of Agriculture in Krakow, Department of Animal Nutrition \\ Mickiewicza 24/28, 30-059 Kraków, Poland \\ ${ }^{3}$ The Kielanowski Institute of Animal Physiology and Nutrition, Polish Academy of Sciences \\ 05-110 Jabłonna Poland \\ ${ }^{4}$ National Research Institute of Animal Production, Experimental Farm \\ 64-122 Pawtowice, Poland
}

(Received 22 July 2008; revised version 13 January 2009; accepted 23 January 2009)

\begin{abstract}
Protected methionine (Smartamine $\mathrm{TM}^{\mathrm{TM}}$; 0,15 or $30 \mathrm{~g} \mathrm{~d}^{-1}$ ) was supplemented to rations containing a high proportion of starch easily (barley) or slowly (maize) fermented in the rumen, fed to preand postpartum dairy cows to study its effect on milk yield and composition, metabolic profile and reproduction. The experiment was carried out on 24 Polish Holstein-Friesian cows, divided 21 days before expected parturition into 3 groups of 8 animals and fed individually. Protected methionine was added to the rations from day 21 before, until 21 day after parturition, but the performance of cows was controlled up to the end of week 12 of lactation.

Protected methionine had no effect on milk yield and composition, metabolic profile, body weight, body condition score, or reproduction indices. Methionine supplementation increased feed intake before parturition $(\mathrm{P}<0.01)$ and blood glucose concentration before parturition and on day 2 after calving $(\mathrm{P}<0.03$ and $\mathrm{P}<0.01$, respectively). The starch source had no influence on the studied parameters.

There was also no statistically significant interaction between the level of protected methionine supplementation and starch sources. These results do not support the hypothesis that feeding cows increased amounts of starch digested in the small intestine together with protected methionine can
\end{abstract}

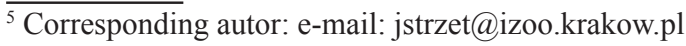


lower energy deficiency and mobilization of energy reserves as well as decrease liver lipidosis by increasing the synthesis of very-low-density lipoproteins.

KEY WORDS: energy, protected methionine, starch, metabolic profile, dairy cows, transition period

\section{INTRODUCTION}

In cows of high genetic value, a decrease in feed intake in the last several days before parturition often creates a negative energy balance (Grummer, 1993, 1995; Drackley, 1999; Keady et al., 2001). In this period the animals are not able to cover intensively increasing energy requirements. As a result of the energy deficit, mobilization of adipose tissue occurs, causing a drastic increase in non-esterified fatty acid (NEFA) concentrations in the blood (Drackley, 1999). Subsequently NEFA are caught by the liver for complete oxidation to $\mathrm{CO}_{2}$ or incomplete oxidation to ketone bodies. A certain proportion of NEFA undergoes re-esterification to triglycerides (TG), whereas some is removed from the liver as a very-low-density lipoprotein (VLDL) fraction (Drackley, 1999; Rukkwamsuk et al., 2000). If the TG concentration in the liver exceeds its removal capability in VLDL, TG is stored in the liver, causing liver lipidosis ("fatty liver"). As a consequence, liver metabolic functions such as gluconeogenesis, ureogenesis and cholesterol and prostaglandin synthesis are reduced (Grummer, 1993, 1995). The rate of fatty degeneration of the liver can be reduced either by minimizing fat reserve mobilization or augmenting removal of TG from the liver as VLDL. Unfortunately, the hepatocytes of ruminants have a lower potential for VLDL synthesis than those of non-ruminants (Kleppe et al., 1988).

Apolipoprotein B is the main protein in VLDL. The concentration of mRNA for this protein is decreased in the liver of cows in early lactation compared with late lactation and the dry period (Cardot et al., 1988; Gruffat et al., 1997). This decrease may be linked with TG accumulation in the liver (Emery et al., 1992; Gruffat et al., 1997).

Studies on the possibility of increasing TG removal from the liver as VLDL have not given univocal answers. Bobe et al. (2004) reported that addition to diets of components thought to increase VLDL synthesis and removal from the liver, such as carnitine, choline, inositol, lysine and methionine, have not brought expected effects in ruminants. It is possible that these components are not deficient in ruminants or they are easily degraded in the rumen. It is also possible that VLDL synthesis in ruminants does not depend on these components.

Methionine is a precursor of apolipoprotein B 100 (apoB100) in the liver (Grummer, 1993). It is also a donor of methyl groups necessary for the synthesis 
of phospholipids, essential components of VLDL. It was supposed that the limited VLDL removal from the liver could result from methionine deficiency (McCarthy et al., 1968). Intravenous infusion of methionine and lysine increased VLDL synthesis in the liver (Durand, 1992). Bauchart et al. (1998) demonstrated that addition of methionine to the diet could increase lipoprotein synthesis in the liver of ruminants, however, the increase of this synthesis was rather small and probably had no biological significance. In another experiment, the dietary addition of $13 \mathrm{~g}$ $\mathrm{d}^{-1}$ of a methionine hydroxy-analogue did not change the TG concentration in the liver of cows under feed restriction (Bertics and Grummer, 1999). Similar effects of hydroxy-analog addition were reported by others (Pullen et al., 1989; Bauchart et al., 1998). On the other hand, Pipenbrink et al. (2004) reported a positive effect of methionine hydroxy-analogue on milk yield without any influence on liver energy metabolism. In this study, the methionine hydroxo-analogue was dosed from day 21 before calving to day 84 of lactation. Brusemeister and Südekum (2006) hypothesize that ruminally protected methionine may positively affect choline metabolism and by this means stimulate VLDL synthesis in the liver.

Starch origin determined its rate of degradation in the rumen and amount digested in the small intestine. On the other hand, intestinal digestion of starch to glucose is more energy-efficient than rumen starch fermentation (Mills et al., 1999). Gluconeogenesis in the liver from propionate requires additional energy expenditure (Nocek and Tamminga, 1991; Rukkwamsuk et al., 1999). In this context, feeding starch digested in the small intestine instead of the rumen in combination with protected methionine could reduce the energy deficit and minimize liver lipidosis by eventual stimulation of VLDL synthesis. Such a physiological reaction could have a positive effect on milk production and reproduction of cows. However in the study of Bertics and Grummer (1999) a simultaneous supply of methionine hydroxy-analog and protected fat did not minimize fatty liver.

The aim of the study was to determine the effect on milk yield and composition, metabolic profile and reproduction of adding protected methionine and different starch sources (easily or slowly fermented in the rumen) to the diets for transition cows.

\section{MATERIAL AND METHODS}

\section{Experimental design, animals and management}

The experiment was carried out on 24 Polish Holstein-Friesian cows. On day 21 before expected calving the cows were allotted by the analog method into 3 groups of 8 animals, taking into account body weight $(547-738 \mathrm{~kg})$, proportion of 
Holstein-Friesian blood, parity, body condition score (BCS) and maximal milk yield in previous lactations.

The diets for cows were balanced according to IZ-INRA (2001) standards. They were then supplemented from day 21 before expected calving up to day 21 of lactation with 0,15 or $30 \mathrm{~g} \mathrm{~d}^{-1}$ (group I, II and III, respectively) of ruminally protected methionine (Smartamine ${ }^{\mathrm{MT}} \mathrm{M}$, Addiseo). According to the supplier, Smartamine contained $70 \%$ methionine of which $90 \%$ was protected from rumen degradation. Cows of each group were fed concentrate containing either ground barley (subgroup B) or ground maize grain (subgroup M) from day 21 before expected calving up to the end of week 12 of lactation (Table 1).

Table 1. Concentrate composition, $\%$

\begin{tabular}{lcc}
\hline \multirow{2}{*}{ Items } & \multicolumn{2}{c}{ Concentrate } \\
\cline { 2 - 3 } Ground barley & 65.0 & $\mathrm{M}$ \\
Ground maize & - & 50.0 \\
Wheat bran & 5.0 & 20.0 \\
Soyabean meal & 18.0 & 18.0 \\
Rapeseed meal & 4.0 & 4.0 \\
Sugar beet molasses & 3.0 & 3.0 \\
VITAMIX KW-ZZD ${ }^{1}$ & 3.0 & 3.0 \\
Phosphate 1-Ca & 1.0 & 1.0 \\
Limestone & 1.0 & 1.0 \\
\hline${ }^{1}$ in 1 kg, g: P 60, Ca 150, Mg 30, Na 10; mg: Cu 1000, Zn 12000, Mn 8000, vit. E 3000; IU: vit. \\
A 1000000, vit. D 130000
\end{tabular}

Cows were kept tied in individual straw-bedded stalls enabling individual control of concentrate and forage intake, with permanent access to drinking water and salt-licks. The basal diet consisted of maize silage, lucerne silage, whole barley plant (45\%) - lucerne (55\%) silage, sugar beet pulp silage, wet brewer's grains and meadow hay. Soyabean meal was used as a protein equalizing factor (Table 2). Before calving cows were fed daily rations containing from 11.80 to $7.10 \mathrm{~kg}$ $\mathrm{DM} \mathrm{d}^{-1}$ from the basal diet and 0.88 to $1.79 \mathrm{~kg} \mathrm{DM} \mathrm{d}^{-1}$ from concentrate. During lactation the rations consisted of 11.89 to 13.42 and 13.42 to $11.89 \mathrm{~kg} \mathrm{DM} \mathrm{d}^{-1}$ of basal diet and concentrates, respectively. Vitamins and minerals were also supplemented in drinking water as Aquablend, Superzinc and Hydrovit (Aqua-Blend, The Netherland).

Cows were fed individually twice daily, with maize silage, sugar beet pulp silage and wet brewer's grains in the morning, and maize silage, lucerne silage, barley+lucerne silage and meadow hay in the afternoon before milking. Concentrates were given separately from forages 3 times per day in equal 
portions. Refusals were measured every morning. Representative samples of refusals of the basal diet were collected and kept frozen until analysis.

Animals were weighed on days 21 and 7 before expected calving and on day 2 after calving. BSC was estimated according to Edmonson et al. (1989). Milk production was measured daily using Milk Masters. Milk samples were taken in 7-day intervals from the morning and afternoon milkings and stored at $4^{\circ} \mathrm{C}$, but no longer than 2 weeks, until analysis.

On day 5 before expected calving, jugular blood samples were taken and serum was kept at $-20^{\circ} \mathrm{C}$ until analysed. Data on insemination index, number of days to first service, length of service period and open days were collected.

\section{Chemical analysis}

Feeds and refusals were analysed according to AOAC (1990) and the fermentation products in silages by gas chromatography (Varian 3400 and Autosampler $8200 \mathrm{CX}$, column DB-SFAP Megabore 30 meter long and ID 53 $\mu$; initial temperature of column was $80^{\circ} \mathrm{C}$ increased by $7^{\circ} \mathrm{C} / \mathrm{min}$ until $270^{\circ}$, injection temperature was $200^{\circ} \mathrm{C}$, detection temperature, $260^{\circ} \mathrm{C}$ ). Silage $\mathrm{pH}$ was measured potentiometrically. Milk composition and somatic cell count (SCC) was determined using a Milko-Scan FT 120 (Foss Electric, Denmark).

Serum non-esterified fatty acids were estimated colorimetrically using acylCoA synthetase, oxidase and peroxidase (WAKO Reagents). D-3 hydroxybutyric acid (BHBA) was determined in a kinetic enzymatic reaction using a Cobas-Bio analyzer (Roche) and a high-sensitivity reagent kit (RANDOX). Glucose, urea, albumin and aspartate aminotransferase (AST) were determined using a VITROS 950 analyzer (Ortho-Clinical Diagnostic; Test Methodology Manual, 1997), insulin and progesterone by radioimmunoassay (BioSource INS-IRMA Kit and BioSource PROG-RIA-CT Kits).

\section{Calculations and statistical analysis}

The energy and protein values of feeds were calculated according to IZ-INRA (2001) methods using WINWAR 1.6 (2000) and INRAtion 2.63 (1998/99) software.

The results were subjected to two-way analysis of variance using the GLM procedure of SAS (2001). The differences between treatments were then estimated using the LSM method. $\mathrm{P}<0.05$ was considered significant. For some traits, normal distribution was not achieved, and for them the analysis of variance was carried out on data submitted to logarithmic transformation. Graphs describing dry mater, energy and protein intake were prepared using Excel for Windows software. 


\section{RESULTS AND DISCUSSION}

The chemical composition and nutritive value of feeds and refusals of basal diets are shown in Table 2. Concentrates for subgroups $\mathrm{M}$ and $\mathrm{B}$ were isoenergetic and iso-nitrogenous (crude protein and PDIN), but concentrate $\mathrm{M}$ contained slightly more PDIE and crude fibre. Both concentrates had similar contents of $\mathrm{N}$-free extractives with starch as a main component. Chemical composition and nutritive value of refusals before calving were similar in both subgroups, however, refusals $\mathrm{M}$ had slightly higher crude protein and lower crude fibre contents. The higher content of $\mathrm{N}$-free extractives in refusals of subgroup $\mathrm{M}$ indicates a lower intake of this component by cows.

Refusals during lactation in both subgroups contained similar levels of protein and energy, but refusals of subgroup $M$ had more crude fibre and less $\mathrm{N}$-free extractives, indicating a higher starch intake by this subgroup (Table 2).

Table 2. Chemical composition and nutritive value of feedstuffs

\begin{tabular}{|c|c|c|c|c|c|c|c|c|c|}
\hline \multirow[b]{2}{*}{ Components } & \multirow{2}{*}{$\begin{array}{c}\text { Dry } \\
\text { matter, } \\
\mathrm{g} \mathrm{kg}^{-1}\end{array}$} & \multicolumn{5}{|c|}{ In $\mathrm{g} \mathrm{kg}^{-1} \mathrm{DM}$} & \multirow{2}{*}{$\begin{array}{c}\mathrm{PDIN}^{3} \\
\mathrm{~g} \mathrm{~kg}^{-1} \\
\mathrm{DM}\end{array}$} & \multirow{2}{*}{$\begin{array}{c}\mathrm{PDIE}^{3} \\
\mathrm{~g} \mathrm{~kg}^{-1} \\
\mathrm{DM}\end{array}$} & \multirow{2}{*}{$\begin{array}{l}\mathrm{UFL} \\
\mathrm{kg}^{-1} \\
\mathrm{DM}\end{array}$} \\
\hline & & ash & $\begin{array}{l}\text { crude } \\
\text { protein }\end{array}$ & $\begin{array}{l}\text { ether } \\
\text { extract }\end{array}$ & $\begin{array}{l}\text { crude } \\
\text { fibre }\end{array}$ & $\mathrm{NFE}^{2}$ & & & \\
\hline Maize silage $^{1}$ & 406 & 38.2 & 89.5 & 34.5 & 207.3 & 630.5 & 55.0 & 72.1 & 0.90 \\
\hline Lucerne silage $^{1}$ & 353 & 101.1 & 177.9 & 26.9 & 320.8 & 373.3 & 101.1 & 66.6 & 0.75 \\
\hline $\begin{array}{l}\text { Barley + lucerne } \\
\text { silage }^{1}\end{array}$ & 353 & 81.5 & 154.1 & 15.6 & 179.0 & 569.8 & 90.7 & 66.3 & 0.71 \\
\hline Sugar beet pulp silage & 200 & 40.4 & 104.3 & 10.0 & 233.3 & 612.0 & 63.5 & 97.1 & 0.99 \\
\hline Meadow hay & 842 & 85.9 & 101.0 & 12.5 & 313.9 & 486.7 & 62.9 & 77.6 & 0.75 \\
\hline Wet brewer's grains & 255 & 34.9 & 239.1 & 16.9 & 190.9 & 518.2 & 177.6 & 167.7 & 0.87 \\
\hline Wheat bran & 870 & 76.1 & 165.4 & 31.1 & 102.8 & 624.6 & 109.5 & 94.9 & 0.89 \\
\hline Ground barley & 874 & 22.7 & 126.8 & 19.7 & 42.2 & 788.6 & 83.0 & 104.4 & 1.18 \\
\hline Ground maize & 869 & 15.3 & 106.1 & 43.6 & 32.4 & 802.6 & 86.7 & 136.6 & 1.30 \\
\hline Soyabean oilmeal & 911 & 76.7 & 516.4 & 23.6 & 42.7 & 340.6 & 367.9 & 252.1 & 1.21 \\
\hline Rapeseed oilmeal & 884 & 73.8 & 376.8 & 36.1 & 139.4 & 373.9 & 244.2 & 157.2 & 1.07 \\
\hline Concentrate mixture B & 880 & 73.3 & 205.0 & 30.8 & 46.0 & 644.9 & 140.0 & 127.0 & 1.10 \\
\hline Concentrate mixture $\mathrm{M}$ & 878 & 76.5 & 202.1 & 32.2 & 50.0 & 639.2 & 146.0 & 142.0 & 1.12 \\
\hline \multicolumn{10}{|l|}{ Refusals before calving } \\
\hline subgroup B & 236 & 58.0 & 142.6 & 31.7 & 314.7 & 453.0 & 91.1 & 85.2 & 0.80 \\
\hline subgroup M & 296 & 73.6 & 152.9 & 33.1 & 237.0 & 503.4 & 94.8 & 84.9 & 0.80 \\
\hline \multicolumn{10}{|l|}{ Refusals after calving } \\
\hline subgroup B & 274 & 81.5 & 154.9 & 29.6 & 300.3 & 433.7 & 93.2 & 84.3 & 0.79 \\
\hline subgroup M & 318 & 78.9 & 150.8 & 29.5 & 346.6 & 394.2 & 91.7 & 84.1 & 0.78 \\
\hline
\end{tabular}

${ }^{1}$ fermentation products (PF) - acetate, butyrate, lactate: maize silage $23.05 \mathrm{~g} \mathrm{~kg}^{-1}$ feed; $\mathrm{pH} 4.80$; lucerne silage $24.70 \mathrm{~g} / \mathrm{kg}^{-1}$, $\mathrm{pH} 5.02$; barley + lucerne silage $31.06 \mathrm{~g} \mathrm{~kg}^{-1}, \mathrm{pH} 5.12 ;{ }^{2} \mathrm{NFE}-$ $\mathrm{N}$-free extractives; ${ }^{3}$ units of IZ-INRA (2001) standards 
Differences between the subgroups in the $\mathrm{N}$-free extractives content in refusals before and after calving are difficult to interpret.

Intake of feeds and nutrients is shown in Tables 3 and 4 and in Figures 1 and 2. In the last week before calving, cows fed rations supplemented with different

Table 3. Daily feed and nutrient intake before calving

\begin{tabular}{|c|c|c|c|c|c|c|c|c|c|}
\hline \multirow{2}{*}{ Items } & \multicolumn{3}{|c|}{ Smartamine, $\mathrm{g} \mathrm{d}^{-1}$} & \multirow{2}{*}{$\mathrm{P}^{1}$} & \multicolumn{2}{|c|}{ Starch source } & \multirow{2}{*}{$\mathrm{P}$} & \multirow{2}{*}{$\mathrm{SE}^{2}$} & \multirow{2}{*}{$\begin{array}{c}\text { P for } \\
\text { interaction }\end{array}$} \\
\hline & 0 & 15 & 30 & & $\mathrm{~B}$ & $\mathrm{M}$ & & & \\
\hline \multicolumn{10}{|l|}{ Last week before calving } \\
\hline DM - total, kg & $10.08^{\mathrm{a}}$ & $11.11^{\mathrm{b}}$ & $11.09^{\mathrm{b}}$ & 0.01 & 10.80 & 10.73 & 0.65 & 0.12 & 0.64 \\
\hline - basal diet, $\mathrm{kg}$ & $8.30^{\mathrm{b}}$ & $9.32^{\mathrm{b}}$ & $9.30^{\mathrm{b}}$ & 0.01 & 9.00 & 8.94 & 0.65 & 0.12 & 0.65 \\
\hline - concentrate, $\mathrm{kg}$ & 1.79 & 1.79 & 1.79 & 0.42 & 1.79 & 1.79 & 0.36 & 0.00 & 0.42 \\
\hline crude protein, $\mathrm{kg}$ & $1.529^{\mathrm{a}}$ & $1.625^{\mathrm{b}}$ & $1.610^{\mathrm{b}}$ & 0.01 & 1.591 & 1.586 & 0.82 & 0.01 & 0.28 \\
\hline PDIN, kg & $0.991^{\mathrm{a}}$ & $1.049^{\mathrm{b}}$ & $1.038^{\mathrm{b}}$ & 0.01 & 1.024 & 1.028 & 0.74 & 0.01 & 0.26 \\
\hline PDIE, kg & $0.937^{\mathrm{a}}$ & $1.011^{\mathrm{b}}$ & $1.004^{\mathrm{b}}$ & 0.01 & 0.978 & 0.990 & 0.33 & 0.01 & 0.41 \\
\hline UFL & $9.11^{\mathrm{a}}$ & $10.02^{\mathrm{b}}$ & $9.99^{\mathrm{b}}$ & 0.01 & 9.71 & 9.70 & 0.90 & 0.11 & 0.71 \\
\hline \multicolumn{10}{|c|}{ Three weeks before calving } \\
\hline DM - total, $\mathrm{kg}$ & $10.06^{\mathrm{a}}$ & $10.96^{\mathrm{b}}$ & $10.96^{\mathrm{b}}$ & 0.01 & 10.73 & 10.59 & 0.34 & 0.11 & 0.53 \\
\hline - basal diet, $\mathrm{kg}$ & $8.58^{\mathrm{a}}$ & $9.44^{\mathrm{b}}$ & $9.47^{\mathrm{b}}$ & 0.01 & 9.24 & 9.08 & 0.33 & 0.11 & 0.56 \\
\hline - concentrate, $\mathrm{kg}$ & 1.48 & 1.52 & 1.49 & 0.33 & 1.49 & 1.51 & 0.46 & 0.01 & 0.76 \\
\hline crude protein, $\mathrm{kg}$ & $1.31^{\mathrm{a}}$ & $1.43^{\mathrm{b}}$ & $1.40^{\mathrm{b}}$ & 0.01 & 1.38 & 1.38 & 0.93 & 0.01 & 0.51 \\
\hline PDIN, kg & $0.831^{\mathrm{a}}$ & $0.911^{\mathrm{b}}$ & $0.891^{\mathrm{b}}$ & 0.01 & 0.871 & 0.882 & 0.52 & 0.01 & 0.55 \\
\hline PDIE, kg & $0.850^{\mathrm{a}}$ & $0.923^{\mathrm{b}}$ & $0.912^{\mathrm{b}}$ & 0.01 & 0.892 & 0.901 & 0.21 & 0.01 & 0.47 \\
\hline UFL & $8.95^{\mathrm{a}}$ & $9.76^{\mathrm{b}}$ & $9.74^{\mathrm{b}}$ & 0.01 & 9.52 & 9.45 & 0.56 & 0.01 & 0.56 \\
\hline
\end{tabular}

${ }^{1} \mathrm{P}$ - probability; ${ }^{2} \mathrm{SE}$ - standard error of mean; ${ }^{3}$ interaction protected methionine (Smartamine) $\times$ starch source; differences between the means within the row with different letters are statistically significant

doses of protected methionine consumed (Table 3) significantly more DM $(\mathrm{P}<0.01)$ than cows of the control group, which resulted from a higher intake of the basal diet $(\mathrm{P}<0.01)$. As a result of increased intake of $\mathrm{DM}$, the methioninesupplemented cows also consumed more crude protein, PDIN, PDIE and UFL.

The source of starch in the concentrate had no influence on DM and nutrient intake before calving. The above tendencies were found both in the last week and in the last three weeks prepartum.

The positive effect of protected methionine supplement on feed intake before calving could be ascribed to more efficient liver function. A "healthier" liver means less propionate, ketone bodies and ammonia, etc. in the blood, which in turn may stimulate higher DM intake. Methionine, being a donor of methyl groups, could hypothetically provoke more effective triglyceride oxidation or stimulate VLDL synthesis (Drackley, 1999; Brusemeister and Südekum, 2006). 
Table 4. Daily intake of feed and nutrients lactation period

\begin{tabular}{|c|c|c|c|c|c|c|c|c|c|}
\hline \multirow{2}{*}{ Items } & \multicolumn{3}{|c|}{ Smartamine, $\mathrm{g} \mathrm{d}^{-1}$} & \multirow{2}{*}{$\mathrm{P}$} & \multicolumn{2}{|c|}{ Starch source } & \multirow{2}{*}{$\mathrm{P}$} & \multirow{2}{*}{$\mathrm{SE}$} & \multirow{2}{*}{$\begin{array}{c}\mathrm{P} \text { for } \\
\text { interaction }\end{array}$} \\
\hline & 0 & 15 & 30 & & $\mathrm{~B}$ & $\mathrm{M}$ & & & \\
\hline \multicolumn{10}{|l|}{ First week of lactation } \\
\hline DM - total, kg & 12.65 & 12.76 & 12.78 & 0.60 & 12.78 & 12.68 & 0.37 & 0.05 & 0.38 \\
\hline - basal diet, $\mathrm{kg}$ & 9.10 & 9.21 & 9.23 & 0.61 & 9.23 & 9.13 & 0.37 & 0.05 & 0.38 \\
\hline - concentrate, $\mathrm{kg}$ & 3.55 & 3.55 & 3.55 & 1.00 & 3.55 & 3.55 & 1.00 & 0.00 & 0.99 \\
\hline crude protein, $\mathrm{kg}$ & 1.95 & 1.97 & 1.97 & 0.62 & 1.97 & 1.95 & 0.21 & 0.01 & 0.38 \\
\hline PDIN, kg & 1.28 & 1.29 & 1.29 & 0.62 & 1.28 & 1.29 & 0.53 & 0.00 & 0.38 \\
\hline PDIE, kg & 1.23 & 1.24 & 1.24 & 0.63 & 1.22 & 1.25 & 0.01 & 0.01 & 0.39 \\
\hline UFL & 11.81 & 11.89 & 11.90 & 0.64 & 11.87 & 11.86 & 0.86 & 0.04 & 0.40 \\
\hline \multicolumn{10}{|l|}{ First 12 weeks of lactation } \\
\hline DM - total, kg & 20.61 & 21.14 & 20.65 & 0.41 & 20.82 & 20.78 & 0.89 & 0.16 & 0.90 \\
\hline - basal diet, $\mathrm{kg}$ & 11.21 & 11.57 & 11.26 & 0.44 & 11.39 & 11.30 & 0.72 & 0.11 & 0.99 \\
\hline - concentrate, $\mathrm{kg}$ & 9.40 & 9.57 & 9.39 & 0.50 & 9.43 & 9.47 & 0.75 & 0.06 & 0.61 \\
\hline crude protein, $\mathrm{kg}$ & 3.68 & 3.79 & 3.72 & 0.28 & 3.74 & 3.72 & 0.77 & 0.03 & 0.97 \\
\hline PDIN, kg & 2.44 & 2.51 & 2.46 & 0.32 & 2.44 & 2.49 & 0.16 & 0.02 & 0.97 \\
\hline PDIE, kg & 2.18 & 2.23 & 2.18 & 0.48 & 2.13 & 2.26 & 0.01 & 0.02 & 0.92 \\
\hline UFL & 19.68 & 20.11 & 19.68 & 0.43 & 19.75 & 19.90 & 0.64 & 0.14 & 0.84 \\
\hline
\end{tabular}
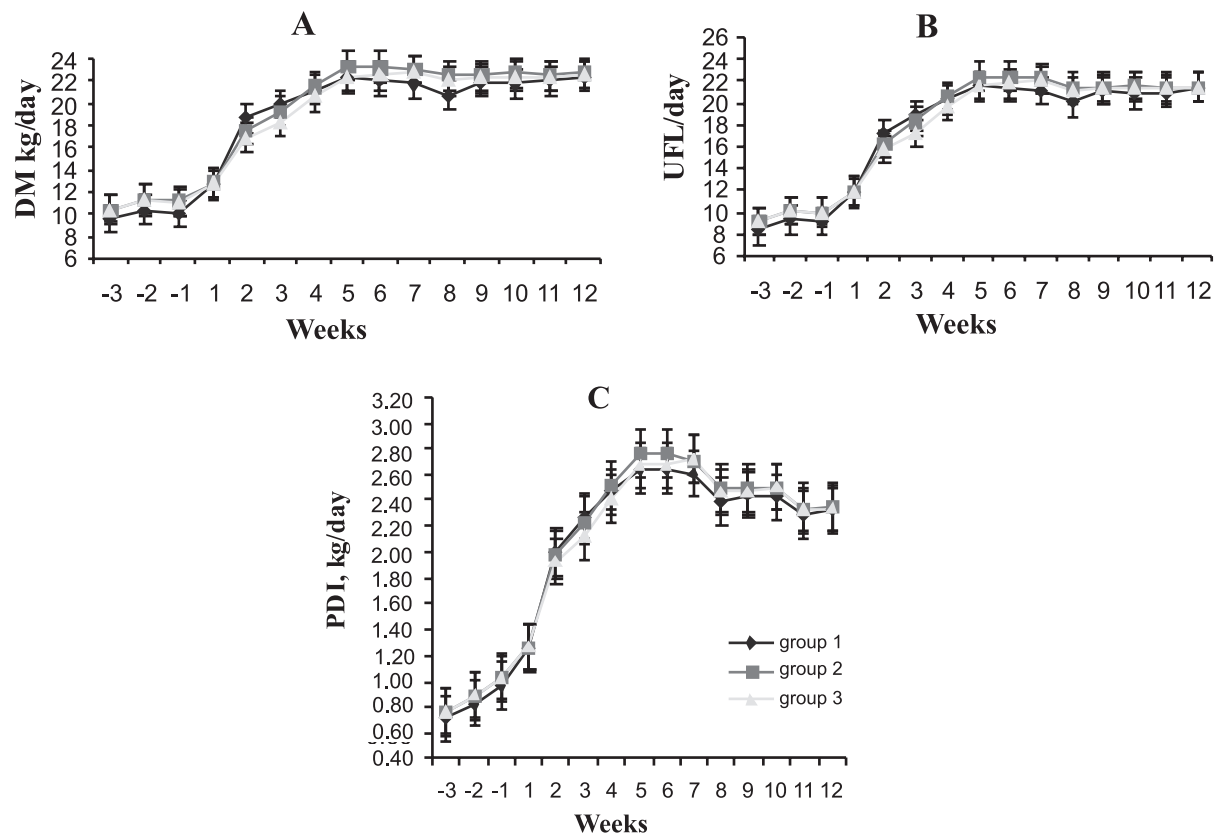

Figure 1. Effect of dietary protected methionine $\left(0,15,30 \mathrm{~g} \mathrm{~d}^{-1}\right)$ on daily intake of DM (A), UFL (B) and PDI (C) 


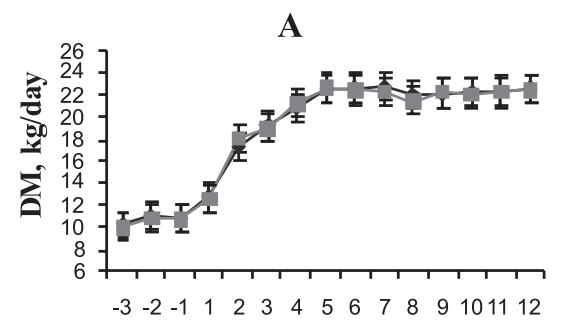

Weeks

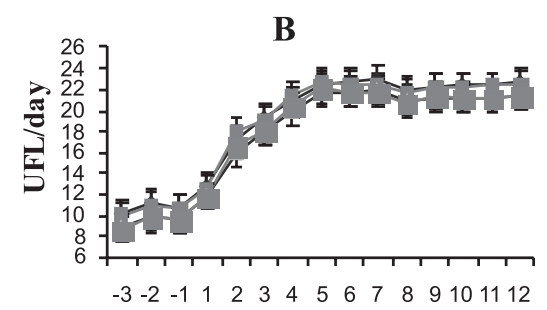

Weeks

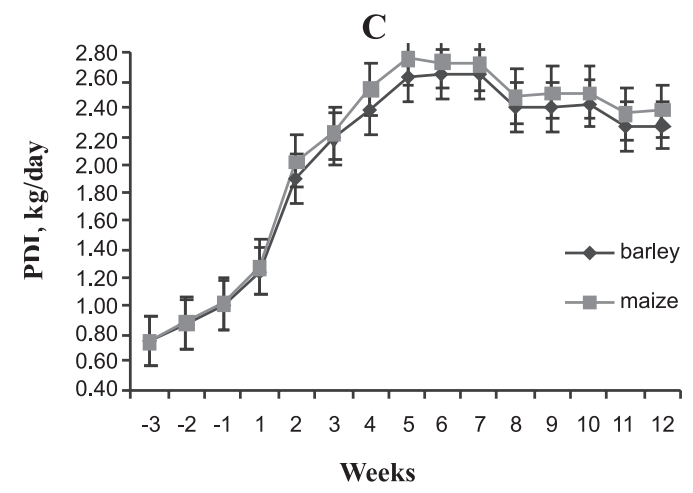

Figure 2. Effect of starch source on daily intake of DM (A), UFL (B) and PDI (C)

Supplementation of protected methionine did not influence, in any analysed period after calving (Table 4), total or basal diet daily DM intake and, consequently, protein and energy intake, which is in line with other authors (Sloan, 1997; Pisulewski et al., 2002).

The starch source also did not affect DM intake of total and basal diet and concentrates in lactating cows, however, the cows fed concentrate containing maize consumed more $(\mathrm{P}<0.01$; Figure 2$) \mathrm{PDIE}$, which was caused by the higher PDIE content in maize concentrate (Table 2). The lack of effect of starch source on feed intake is not surprising since the compared rations were isoenergetic and generally the chemical composition and nutritive value of refusals did not point to preferential starch (NFE) intake by any subgroup. Interaction between protected methionine supplementation and starch source on DM and nutrient intake also appeared not to be significant.

Mean daily milk yield amounted to $36.6 \mathrm{~kg}$ (Table 5) and neither protected methionine supplementation nor starch source affected total or mean daily milk yield, which agrees with the results of other experiments (Sloan, 1997; Younge et al., 2001; Pisulewski et al., 2002). Same authors (Rulquin et al., 1993; Sloan, 1997; Younge et al., 2001) reported that protected methionine supplementation 
Table 5. Milk production and composition in weeks 1 to 12 of lactation

\begin{tabular}{|c|c|c|c|c|c|c|c|c|c|}
\hline \multirow{2}{*}{ Items } & \multicolumn{3}{|c|}{ Smartamine, $\mathrm{g} \mathrm{d}^{-1}$} & \multirow{2}{*}{$P$} & \multicolumn{2}{|c|}{ Starch source } & \multirow{2}{*}{$\mathrm{P}$} & \multirow{2}{*}{$\mathrm{SE}$} & \multirow{2}{*}{$\begin{array}{c}\mathrm{P} \text { for } \\
\text { interaction }\end{array}$} \\
\hline & 0 & 15 & 30 & & B & $\mathrm{M}$ & & & \\
\hline $\begin{array}{l}\text { Total milk production, } \\
\mathrm{kg} \mathrm{cow}^{-1}\end{array}$ & 3052.5 & 3143.6 & 3023.3 & 0.61 & 3014.1 & 3132.1 & 0.26 & 50.5 & 0.38 \\
\hline $\begin{array}{l}\text { Daily milk production, } \\
\mathrm{kg} \mathrm{d}^{-1}\end{array}$ & 36.34 & 37.42 & 35.99 & 0.61 & 35.88 & 37.29 & 0.26 & 0.60 & 0.38 \\
\hline \multicolumn{10}{|l|}{ Milk composition, $\%$} \\
\hline dry matter & 13.02 & 12.51 & 12.80 & 0.47 & 12.70 & 12.86 & 0.65 & 0.16 & 0.85 \\
\hline non-fat solids & 8.99 & 8.46 & 8.67 & 0.30 & 8.70 & 8.72 & 0.94 & 0.13 & 0.88 \\
\hline protein & 3.21 & 3.18 & 3.31 & 0.18 & 3.19 & 3.28 & 0.15 & 0.03 & 0.46 \\
\hline fat & 3.96 & 4.05 & 4.12 & 0.38 & 3.98 & 4.11 & 0.21 & 0.05 & 0.77 \\
\hline lactose & 4.68 & 4.67 & 4.63 & 0.71 & 4.67 & 4.64 & 0.65 & 0.02 & 0.85 \\
\hline urea, $\mathrm{mg}^{-1}$ & 225 & 223 & 230 & 0.91 & 240 & 212 & 0.05 & 1 & 0.72 \\
\hline $\mathrm{NSC}^{1}$ & 185 & 210 & 143 & 0.55 & 204 & 154 & 0.87 & 24 & 0.26 \\
\hline
\end{tabular}

${ }^{1} \mathrm{NSC}$ - number of somatic cells, $\mathrm{ml}^{-1}$

increased milk protein content, however, such an effect could be expected in cows fed rations deficient in methionine digested in the small intestine. In our experiment, supplementation of Smartamine only slightly increased protein and fat contents in milk, which may suggest a lack of substantial deficiency in our control diet. A similar lack of protected methionine effect on milk composition was found in the experiments of Younge et al. (2001) and Pisulewski et al. (2002).

Starch source did not affect milk composition but, unexpectedly, the cows of subgroup B produced milk containing more urea $(\mathrm{P}<0.05$; Table 5). One would rather expect the opposite results since higher availability of barley than maize starch in the rumen could deliver more substrate (energy) to capture ammonia in microbial protein.

The efficiency of milk production did not depend on Smartamine supplementation or starch source (Table 6). For the production of $1 \mathrm{~kg}$ of milk the cows in the experiment used on average about $300 \mathrm{~g}$ of concentrates, $600 \mathrm{~g} \mathrm{DM}$, $63 \mathrm{~g}$ PDI and 0.57 UFL and these results are somewhat higher than IZ-INRA (2001) standards.

Table 6. Efficiency of milk production in weeks 1 to 12 of lactation, $\mathrm{kg}$ consumed per $\mathrm{kg}$ of milk

\begin{tabular}{|c|c|c|c|c|c|c|c|c|c|}
\hline \multirow{2}{*}{ Item } & \multicolumn{3}{|c|}{ Smartamine, $\mathrm{g} \mathrm{d}^{-1}$} & & \multicolumn{2}{|c|}{ Starch source } & \multirow{2}{*}{$\mathrm{P}$} & \multirow{2}{*}{ SE } & \multirow{2}{*}{$\begin{array}{c}\mathrm{P} \text { for } \\
\text { interaction }\end{array}$} \\
\hline & 0 & 15 & 30 & & $\mathrm{~B}$ & $\mathrm{M}$ & & & \\
\hline Concentrate & 0.308 & 0.300 & 0.313 & 0.75 & 0.304 & 0.310 & 0.78 & 0.00 & 0.30 \\
\hline DM & 0.595 & 0.585 & 0.608 & 0.81 & 0.593 & 0.600 & 0.78 & 0.01 & 0.22 \\
\hline Crude protein & 0.106 & 0.105 & 0.110 & 0.72 & 0.106 & 0.108 & 0.87 & 0.00 & 0.28 \\
\hline PDI & 0.063 & 0.062 & 0.064 & 0.58 & 0.061 & 0.065 & 0.47 & 0.00 & 0.13 \\
\hline UFL & 0.569 & 0.557 & 0.579 & 0.76 & 0.562 & 0.574 & 0.66 & 0.01 & 0.28 \\
\hline
\end{tabular}


The metabolic profiles of cows on days 1-2 before calving and 21-28 of lactation are given in Table 7. Addition of protected methionine resulted in a significant increase in blood serum glucose content before calving and on days 1-2 after calving. Before calving the effect of Smartamine was already seen when $15 \mathrm{~g} \mathrm{~d}^{-1}$ of additive were used, whereas on days 1-2 such an effect was found only when $30 \mathrm{~g}$ were applied. The higher post-partum serum glucose content was in line with higher serum insulin level $(\mathrm{P}<0.02)$. The higher serum glucose content may testify to more effective gluconeogenesis in the liver of methionine-supplemented cows. It is possible that methionine stimulating

Table 7. Blood serum parameters before and after calving

\begin{tabular}{|c|c|c|c|c|c|c|c|c|c|}
\hline \multirow{2}{*}{ Items } & \multicolumn{3}{|c|}{ Smartamine, $\mathrm{g} \mathrm{d}^{-1}$} & \multirow{2}{*}{$\mathrm{P}$} & \multicolumn{2}{|c|}{ Starch source } & \multirow{2}{*}{$\mathrm{P}$} & \multirow{2}{*}{ SE } & \multirow{2}{*}{$\begin{array}{c}\text { P for } \\
\text { interaction }\end{array}$} \\
\hline & 0 & 15 & 30 & & $\mathrm{~B}$ & $\mathrm{M}$ & & & \\
\hline \multicolumn{10}{|l|}{ Last week before calving } \\
\hline glucose, $\mathrm{mmol} \mathrm{l}^{-1}$ & $1.65^{\mathrm{a}}$ & $2.54^{\mathrm{b}}$ & $2.75^{b}$ & 0.03 & 2.35 & 2.31 & 0.76 & 0.08 & 0.16 \\
\hline $\mathrm{BUN}, \mathrm{mmol} \mathrm{1} \mathrm{l}^{-1}$ & 4.42 & 3.97 & 3.74 & 0.58 & 3.96 & 4.13 & 0.77 & 0.22 & 0.81 \\
\hline NEFA, mmol $1^{-1}$ & 0.26 & 0.32 & 0.24 & 0.90 & 0.29 & 0.26 & 0.84 & 0.04 & 0.60 \\
\hline BHBA, mmoll ${ }^{-1}$ & 0.71 & 0.75 & 0.69 & 0.81 & 0.74 & 0.69 & 0.53 & 0.04 & 0.22 \\
\hline insulin, $\mathrm{uU}^{-1}$ & 9.37 & 12.69 & 13.38 & 0.34 & 13.87 & 10.19 & 0.17 & 1.13 & 0.41 \\
\hline \multicolumn{10}{|l|}{ Days 1-2 of lactation } \\
\hline glucose, $\mathrm{mmoll}^{-1}$ & $0.83^{\mathrm{a}}$ & $0.61^{\mathrm{a}}$ & $1.84^{\mathrm{b}}$ & 0.01 & 1.24 & 1.62 & 0.06 & 0.13 & 0.23 \\
\hline NEFA, mmoll-1 & 0.47 & 0.30 & 0.24 & 0.24 & 0.43 & 0.25 & 0.15 & 0.06 & 0.75 \\
\hline BHBA, mmol $1^{-1}$ & 1.74 & 1.70 & 1.14 & 0.31 & 1.66 & 1.40 & 0.21 & 0.22 & 0.58 \\
\hline insulin, ${\mathrm{uU} 1^{-1}}^{-1}$ & $5.85^{\mathrm{a}}$ & $6.63^{\mathrm{a}}$ & $8.51^{\mathrm{b}}$ & 0.02 & 8.82 & 8.75 & 0.88 & 0.89 & 0.52 \\
\hline albumin, $\mathrm{g}^{-1}$ & 26.75 & 26.63 & 27.63 & 0.64 & 27.33 & 26.67 & 0.49 & 0.43 & 0.90 \\
\hline AST, $\mathrm{U}^{-1}$ & 134.9 & 174.2 & 139.9 & 0.85 & 136.7 & 162.7 & 0.67 & 17.1 & 0.92 \\
\hline \multicolumn{10}{|l|}{ 21-28 days of lactation } \\
\hline BUN, mmol l-1 & 4.65 & 4.12 & 4.81 & 0.63 & 4.63 & 4.43 & 0.71 & 0.28 & 0.98 \\
\hline albumin, $\mathrm{g}^{-1}$ & 26.38 & 28.75 & 28.38 & 0.95 & 28.33 & 28.67 & 0.78 & 0.52 & 0.93 \\
\hline $\mathrm{AST}, \mathrm{Ul}^{-1}$ & 103.13 & 104.63 & 108.75 & 0.98 & 112.92 & 98.08 & 0.26 & 5.63 & 0.75 \\
\hline progesterone, $\mathrm{ng} \mathrm{ml}^{-1}$ & 3.46 & 1.22 & 1.84 & 0.19 & 1.80 & 2.56 & 0.41 & 0.49 & 0.39 \\
\hline
\end{tabular}

VLDL synthesis in the liver (Bauchart et al., 1998; Brusemeister and Südekum, 2006) decreased liver lipidosis, causing better conditions for glucose synthesis. Unfortunately, such an increase in blood glucose did not affect DM intake and milk production. On the other hand the starch source had no effect on the studied blood parameters, except for a tendency $(\mathrm{P}=0.06)$ for higher serum glucose on days 1-2 post-partum in cows fed diets with maize concentrate. These animals also had apparently lower NEFA and BHBA serum concentrations, unfortunately not significantly proved. Such a combination of results may point to the improved 
energetic status of cows. More glucose absorbed from the intestines of subgroup M cows might be the main possible factor responsible for this reaction.

None of experimental factors affected body weight or body condition of cows before and after calving (Table 8). There were also no treatment effects on changes in BCS in the periods between before and after calving. According to Grummer (1993) or Drackley (1999), delivery of dietary compounds containing methyl groups should improve energy balance and could limit condition

Table 8 . Body weight and body condition score (BCS) of cows

\begin{tabular}{|c|c|c|c|c|c|c|c|c|c|}
\hline \multirow{2}{*}{ Items } & \multicolumn{3}{|c|}{ Smartamine, $\mathrm{g} \mathrm{d}^{-1}$} & \multirow{2}{*}{$\mathrm{P}$} & \multicolumn{2}{|c|}{ Starch source } & \multirow{2}{*}{$\mathrm{P}$} & \multirow{2}{*}{ SE } & \multirow{2}{*}{$\begin{array}{c}\mathrm{P} \text { for } \\
\text { interaction }\end{array}$} \\
\hline & 0 & 15 & 30 & & $\mathrm{~B}$ & M & & & \\
\hline \multicolumn{10}{|l|}{ Body weight, $\mathrm{kg}$} \\
\hline day 21 before calving & 641.1 & 664.8 & 661.8 & 0.68 & 652.8 & 659.0 & 0.80 & 0.04 & 0.69 \\
\hline day 7 before calving & 668.3 & 669.6 & 671.8 & 0.99 & 666.3 & 673.4 & 0.75 & 0.04 & 0.72 \\
\hline day 7 of lactation & 616.1 & 633.3 & 630.4 & 0.81 & 622.2 & 631.0 & 0.70 & 0.04 & 0.80 \\
\hline \multicolumn{10}{|l|}{$B C S$, points } \\
\hline day 21 before calving & 3.50 & 3.54 & 3.50 & 0.93 & 3.50 & 3.53 & 0.56 & 0.04 & 0.70 \\
\hline day 7 before calving & 3.63 & 3.54 & 3.53 & 0.45 & 3.56 & 3.59 & 0.52 & 0.04 & 0.72 \\
\hline day 7 of lactation & 3.31 & 3.33 & 3.30 & 0.92 & 3.31 & 3.32 & 0.87 & 0.02 & 0.97 \\
\hline
\end{tabular}

losses. Such an effect was not observed in this study. The condition of cows was good at the beginning of the experiment, which might have masked a possible effect of methionine. As above, the reproduction indices studied were not influenced by experimental treatments (Table 9). A possible effect of protected methionine on energy balance was probably too small to influence reproduction of cows.

Table 9. Reproduction performance of cows

\begin{tabular}{|c|c|c|c|c|c|c|c|c|c|}
\hline \multirow{2}{*}{ Items } & \multicolumn{3}{|c|}{ Smartamine, $\mathrm{g} \mathrm{d}^{-1}$} & & \multicolumn{2}{|c|}{ Starch source } & & \multirow{2}{*}{ SE } & \multirow{2}{*}{$\begin{array}{c}\mathrm{P} \text { for } \\
\text { interaction }\end{array}$} \\
\hline & 0 & 15 & 30 & & B & $\mathrm{M}$ & & & \\
\hline Insemination index ${ }^{1}$ & 2.75 & 2.38 & 2.38 & 0.75 & 2.67 & 2.33 & 0.49 & 0.21 & 0.80 \\
\hline Days to first service & 84.3 & 94.1 & 82.9 & 0.59 & 91.6 & 82.5 & 0.35 & 4.78 & 0.24 \\
\hline Service period, days ${ }^{2}$ & 39.6 & 45.8 & 68.5 & 0.75 & 47.8 & 54.8 & 0.45 & 9.59 & 0.59 \\
\hline Open days & 124.0 & 139.8 & 151.4 & 0.44 & 139.4 & 137.3 & 0.90 & 8.08 & 0.74 \\
\hline
\end{tabular}

${ }^{1}$ semen portions used for effective fertilization; ${ }^{2}$ days from first to effective insemination

Generally, the results obtained in our experiment indicate that adding ruminal protected methionine to the diets for transition cows failed to affect milk yield and composition, nutrient conversion, metabolic profile, body weight, BCS and reproduction performance. The only positive effect of protected methionine found was increased serum glucose levels around calving. We hypothesize that this effect could have resulted from donation of methyl groups to the liver. A methionine 
effect on metabolic profile might have been even better marked if the cows had been more fatty, with visible signs of liver lipidosis. However, in the context of our results the application of protected methionine as a preventive treatment against ketosis and liver lipidosis remains disputable.

The lack of effect of starch source on metabolic and productivity indices could have resulted from the relatively low proportion of starch in the diet, particularly before calving.

\section{CONCLUSIONS}

The hypothesis of our study was that feeding transition cows rations containing an additional source of starch digested in the intestine and protected methionine should reduce the energy deficit and body reserve mobilization through an increase in very low density lipid synthesis and a decrease in liver lipidosis. The results of our experiment do not allow this hypothesis to be accepted.

\section{REFERENCES}

AOAC, 1990. Association of Analytical Chemists, Official Methods of Analysis. $15^{\text {th }}$ Edition. Arlington, VA

Bauchart D., Durand D., Gruffat D., Chilliard Y., 1998. Mechanism of liver steatosis in early lactation cows: effects of hepatoprotector agents. In: Proceedings of $60^{\text {th }}$ Cornell Nutrition Conference for Feed Manufacturers, Cornell University, pp. 27-37

Bertics S.J., Grummer R.R., 1999. Effects of fat and methionine hydroxy analog on prevention or alleviation of fatty liver induced by feed restriction. J. Dairy Sci. 82, 2731-2736

Bobe G., Young J.W., Beitz D.C., 2004. Invited review: Pathology, etiology, prevention and treatment of fatty liver in dairy cows. J. Dairy Sci. 87, 3105-3124

Brusemeister F., Südekum K.-H., 2006. Rumen-protected choline for dairy cows: the in situ evaluation of a commercial source and literature evaluation of effects on performance and interactions between methionine and choline metabolism. Anim. Res. 55, 93-104

Cardot P., Mazur A., Pessa M., Chambaz J., Rayssiguier Y., 1988. Expression hepatique du gene d'apolipoproteine B chez la vache au cours de la lactation. Reprod. Nutr. Develop. 28, Suppl. 1, 169-170 (Abstr.)

Drackley J.K., 1999. Biology of dairy cows during the transition period: the final frontier? J. Dairy Sci. 82, 2259-2273

Durand D., Chilliard Y., Bauchart D., 1992. Effects of lysine and methionine on in vivo hepatic secretion of VLDL in high yielding dairy cow. J. Dairy Sci. 75, Suppl. 1, 279 (Abstr.)

Edmonson A.J., Lean I.J., Weaver L.D., Farver T., Webster G., 1989. A body condition scoring chart for Holstein dairy cows. J. Dairy Sci. 72, 68-78

Emery R. S., Leisman J.S., Herdt T.H., 1992. Metabolism of long chain fatty acids by ruminant liver. J. Nutr. $122,832-837$

Gruffat D., Durand D., Chilliard Y., Williams P., Bauchart D., 1997. Hepatic gene expression of apolipoprotein B100 during early lactation in underfed, high producing dairy cows. J. Dairy Sci. $80,657-666$ 
Grummer R.R., 1993. Etiology of lipid-related metabolic disorders in periparturient dairy cows. J. Dairy Sci. 76, 3882-3896

Grummer R.R., 1995. Impact of changes in organic nutrient metabolism on developing feeding strategies to minimize stress during the transition from late pregnancy to early lactation. J. Anim. Sci. 70, 2820-2833

IZ-INRA, 2001. Standards for Cattle, Sheep and Goat Nutrition (in Polish). Research Institute of Animal Production, Krakow-Balice (Poland)

Keady T.W.J., Mayne C.S., Fitzpatrick D.A., McCoy M.A., 2001. Effect of concentrate feed level in lat gestation on subsequent milk yield, milk composition and fertility of dairy cows. J. Dairy Sci. 84, 1468-1479

Kleppe B.B., Aiello R.J., Grummer R.R., Armentano L.E., 1988. Triglyceride accumulation and very low density lipoprotein secretion by rat and goat hepatocytes in vitro. J. Dairy Sci. 71, $1813-1822$

McCarthy R.D., Porter G.A., Griel Jr. L.C., 1968. Bovine ketosis and depressed fat test in milk: a problem of methionine metabolism and serum lipoprotein aberration. J. Dairy Sci. 51, 459-462

Mills J.A.N., France J., Dijkstra J., 1999. A review of starch digestion in the lactating dairy cow and proposals for a mechanistic model: 1 . Dietary starch characterization and ruminal starch digestion. J. Anim. Feed Sci. 8, 291-339

Nocek J.E., Tamminga S., 1991. Site of digestion of starch in the gastrointestinal tract of dairy cows and its effect on milk yield and composition. J. Dairy Sci. 74, 3598-3629

Piepenbrink M.S., Marr A.L., Waldron M.R., Butler W.R., Overton T.R., Vazquez-Anon M., Holt M.D., 2004. Feeding 2-hydroxy-4-(methylthio)-butanoic acid to periparturient dairy cows improves milk production but not hepatic metabolism. J. Dairy Sci. 87, 1071-1084

Pisulewski P.M., Kowalski Z.M., Gurgulu M., 2002. Lactational responses to ruminally-protected methionine in cows fed a low-protein grass silage-based diet. J. Anim. Feed Sci. 11, 189-203

Pullen D.L., Palmquist D.L., Emery R.S., 1989. Effect on days of lactation and methionine hydroxsy analog on incorporation of plasma fatty acids into plasma triglycerides. J. Dairy Sci. 72, 49-58

Rukkwamsuk T., Geelen M.J.H., Kruip T.A.M., Wensing T., 2000. Interrelation of fatty acid composition in adipose tissue, serum and liver of dairy cows during the development of fatty liver postpartum. J. Dairy Sci. 83, 52-59

Rukkwamsuk T., Wensing T., Geelen M.J.H., 1999. Effect fatty liver on hepatic gluconeogenesis in periparturient dairy cows. J. Dairy Sci. 82, 500-505

Rulquin H., Pisulewski P.M., Verité R., Guinard J., 1993. Milk production and composition as a function of postruminal lysine and methionine supply: a nutrient-response approach. Livest. Prod. Sci. 37, 69-90

SAS, 2001. SAS User's Guide: Statistic Release 8.2 SAS Inst. Inc. Cary, NC

Sloan B.K., 1997. Developments in amino acid nutrition of dairy cows. In: P.C. Garnsworthy, J. Wiseman (Editors). Recent Advances in Animal Nutrition. Nottingham University Press, Nottingham, pp. 167-198

Younge B.A., Murphy J.J., Rath M., Sloan B.K., 2001. Effect of dietary absorbable methionine and lysine concentrations on milk production and composition of dairy cows offered grass-silage based diets. Irish J. Agr. Food Res. 40, 1-11 